\title{
ANALYSIS OF FACTORS AFFECTING CRYPTOCURRENCY RETURN DURING THE COVID-19 PANDEMIC
}

\author{
Mangasi Sinurat \\ Sekolah Tinggi Ilmu Ekonomi Bina Karya Tebing Tinggi \\ E-mail: mangasisinurat621@gmail.com
}

\begin{abstract}
This study aims to analyze the effect of Asset Price, Transaction Volume and Market Capitalization on Cryptocurrency Return. This study uses secondary data in the form of a 2020 weekly report accessed at www.Indodax.com. The data analysis method in this study uses panel data regression analysis which is processed using eviews 10 . The partial results show that asset price has a negative and insignificant effect on cryptocurrency returns, transaction volume has a positive and insignificant effect on cryptocurrency returns, market capitalization has a negative and negative effect and not significant to the return of cryptocurrencies. The results of the study simultaneously show that asset price, transaction volume and market capitalization have a negative and insignificant effect on the dependent variable, namely cryptocurrency returns with an R-squared value of $1.1682 \%$. Suggestions for further research are to add other variables that affect cryptocurrency returns such as macroeconomics.
\end{abstract}

Keywords: asset price, transaction volume, market capitalization and return cryptocurrencies.

\section{INTRODUCTION}

Investment is an investment directly or indirectly, as well as short and long term with the aim of obtaining the expected profit or other forms of benefits from the investment itself. One of the most important parts of studying investing is how to measure risk and return. The definition of risk and return will never be the same from one investor to another, even the level of preference for risk and return will never be the same. Every investor who wants to maximize wealth will be attracted to an investment that provides a higher level of expected return compared to other investment opportunities. The expected profit (expected return) is the return that is expected to be obtained by investors in the future.

Global economic conditions before the Covid-19 still showed growth. Even before Covid-19 there were geopolitical tensions between the United States and Iran, a trade war between the United States and the European Union and a trade war between the United States and China. However, overall global economic conditions before Covid-19 were still good and prospective for investment. Not only the global economy, but the national economy is also still quite good as seen from the JCI in early January which had touched the figure of 6300 , this is one of the good and interesting achievements for Indonesia.

The Covid-19 outbreak has had a serious impact on almost all countries in the world, including Indonesia. 19 in Indonesia was first discovered around early or mid-March. The impact is not only in one area, but in almost all areas all existing activities have decreased. One aspect of concern in the midst of the outbreak of the Corona virus is investment. One aspect of concern in the midst of the outbreak of the Corona virus is investment. So that this 
decline caused our JCI to decline to below the 4000 level. This decline is of course also inseparable from investor sentiment, which at that time saw Indonesia getting worse. This sentiment makes investors prefer to withdraw their funds from the capital market so that it certainly makes stock prices decline.

Decisions in choosing investment instruments can be made by buying shares on the Indonesia Stock Exchange (IDX) and selling cryptocurrency markets. The characteristics of the cryptocurrency sales market instrument in Indonesia have similarities with the stock sales market instrument on the IDX in terms of return and risk. Return is measured by capital gains while risk is measured by capital lossor a decrease in the price of an investment instrument the.

Cryptocurrency or crypto currencyincreasingly known by many people in Indonesia. This can be seen from the representation of the blockchain whose impact can be enjoyed directly by the public (consumers), and there are many other potentialswhich can explored, so that interest in cryptocurrencies, generally as an investment instrument, actually only increased sharply after the Bitcoin exchange rate experienced a fairly high spike. The cryptocurrency Bitcoin is the first decentralized peer-to-peer payment network that is fully controlled by its users without any central authority or intermediary.

\section{LITERATURE REVIEW}

\subsection{Asset Price}

The first variable is the asset price that affects the return of a company, the asset can be in the form of a long-term instrument and also has a maturity period and there is regular income during the period of the asset. Meanwhile, according to Buchari Alma (2011) states that "Price is the value of an item expressed in the form of money". Based on the definition of price according to the experts above, it can be concluded that the price is a monetary unit or the value of an item expressed in the form of money that is exchanged in order to obtain ownership rights.

\subsection{Transaction Volume}

Volume is the number of active trades that occur for a particular coin. In general, the larger the volume, the better the number of active trading for the coin, because the coin will become easier to buy and sell. If the coin has low volume, users will have to wait longer to sell and it may be difficult to find a buyer at the current market price. Trading volume can usually be seen as the lower vertical bar on thechart price . Comparing the heights of these bars to one another can show volume activity, relative to other points in the asset price timeline.

\subsection{Market Capitalization}

Market capitalization or what is commonly referred to as market cap is a metric or a measure that shows the value of assets in the digital market. Market caps measure and calculate the value of various digital assets, be it stocks or cryptocurrencies. Market cap in stocks is to measure the value of a security against other value securities. Usually calculated by multiplying the number of shares outstanding at the current share price. While the market capin crypto assets serves to identify the value of digital assets accurately and compare it with other similar assets. A high or low market cap can indicate a type of digital currency that is resistant to volatility. 


\subsection{Return Cryptocurrency}

Profits or returns that will be obtained by the company or known as returns. In relation to investment, returns are expected to make investors prosperous because they invest in these instruments. Horne \& Wachoviz (1998) define return as a benefit which is related with owner that includes cash dividend last year which is paid together with market cost appreciation or capital gain which is realization in the end of the year". Return can also be regarded as an award given for decision making in investment.

\section{conceptual framework}

Based on the discussion above, the conceptual framework in this study can be described as follows:

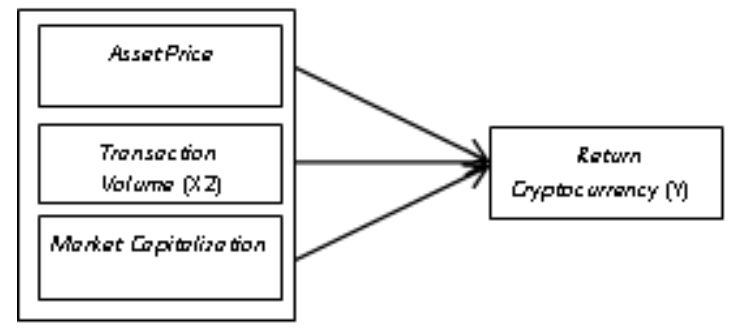

Figure 1. Conceptual Framework

The conceptual framework explains the effect of the independent variable (independent) on the dependent variable, where Asset Price (X1), Transaction Volume (X2) and Market Capitalization (X3) as independent variables and Return Cryptocurrency as the dependent variable. Research Hypothesis Based on the conceptual framework above, the hypotheses proposed in this study are:

H1: Asset Price has a positive and significant effect on Cryptocurrency Return.

H2: Transaction Volume has a positive and significant effect on Cryptocurrency Return.

H3 : Market Capitalization has a positive and significant effect on Cryptocurrency Return.

\section{RESEARCH METHODS}

\subsection{Research Location and Object}

In this study, the object of research is cryptocurrency digital assets and the location of this research is cryptocurrency exchange trading by accessing the official website www.Indodax.com.

\subsection{Population and Sample}

The population in this study there are 2 (two) Cryptocurrency coins with the largest market caps in Indonesia, namely Bitcoin (BTH) and Ethereum (ETH) with an observation time of during the 2020 period where there was a decline in the world economy caused by Covid19 and especially in Indonesia. . While the number of samples or the number of observations in this study amounted to 108 trade transaction weekly report data Asset Digital Cryptocurrency.

\subsection{Data Types and Sources}

This study uses Panel data in the form of weekly transaction reports for digital cryptocurrency trading Bitcoin (BTH) and Ethereum (ETH) taken from the first week of January to the last week of January-december 2020. 


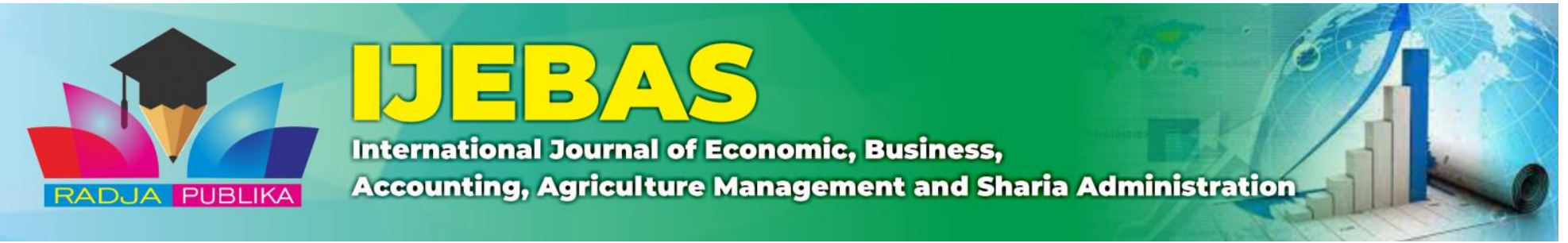

\subsection{Data collection technique}

The data collection technique used in this research is the documentation study method.

\subsection{Data analysis method}

The method used to support this research is a quantitative method and in this study uses panel data regression models, namely the Common Effect Model (CEM), Fixed Effect Model (FEM), and Random Effect Model (REM).

\subsection{Model Selection Technique}

\subsubsection{Chow Test (Chow Test)}

The Chow test is a test conducted to select the best model between the common effect model (CEM) and the fixed effect model (FEM). The Chow test assumes that if there is no structural change in the restricted residual sum square and unrestricted residual sum square equations. The decision-making techniques in the chow test are as follows (Gujarati \& Porter, 2012):

a. If the value is significantly smaller than the standard error of 0.05 , it can be concluded that the best model is panel data regression with a fixed effect model (FEM).

b. If the significant value is greater than the standard error value of 0.05 , it can be concluded that the best model is panel data regression with the common effect model (CEM).

\subsubsection{Hausman Test (Hausman Test)}

To determine the best model between FEM or REM with Hausmen's test. According to Gujarati \& Porter (2012), the fixed effect model assumes that the independent variable is correlated with the error, while the random effect model is correlated with the cross-section in the model.

Technique Decision making on the Hausman test is as follows:

a. If the significant value is $<0.05$, then the best model is panel data regression with FEM.

b. If the significant value is $>0.05$, then the best model is panel data regression with REM.

\subsubsection{Classic assumption test}

The testing stages in the classical assumption test are Normality Test, Heteroscedasticity Test, Multicollinearity Test and Autocorrelation Test.

\subsubsection{Hypothesis test}

In this research, hypothesis testing used is partial test ( $\mathrm{t}$ test) and simultaneous test $(\mathrm{F}$ test). 


\section{RESEARCH RESULTS AND DISCUSSION \\ 4.1 Descriptive statistics}

Table 1 Descriptive Statistics

\begin{tabular}{|l|c|c|c|c|}
\hline & $\begin{array}{c}\text { RETURN } \\
\text { CRYPTOCURRENC } \\
\text { Y }\end{array}$ & $\begin{array}{c}\text { ASSET } \\
\text { PRICE }\end{array}$ & $\begin{array}{c}\text { TRANSACTION } \\
\text { VOLUME }\end{array}$ & $\begin{array}{c}\text { MARKET } \\
\text { CAPITALIZATION }\end{array}$ \\
\hline mean & $\mathbf{0 . 0 7 9 9 2 9}$ & $\mathbf{2 4 0 . 6 5 8 6}$ & $\mathbf{2 7 7 4 , 8 9 4}$ & $\mathbf{1 3 7 9 6 . 1 6}$ \\
\hline median & $\mathbf{0 . 0 3 7 0 3 7}$ & $\mathbf{1 4 8 . 6 6 0 0}$ & $\mathbf{6 8 4 . 3 5 0 0}$ & $\mathbf{4 7 6 2 , 2 4 5}$ \\
\hline Maximum & $\mathbf{1 . 0 0 0 0 0 0 0}$ & $\mathbf{2 3 5 9 , 3 0 0}$ & $\mathbf{1 3 8 5 0 . 4 0}$ & $\mathbf{4 8 6 8 6 5 . 0}$ \\
\hline Minimum & $\mathbf{- 0 . 9 8 1 4 8 1}$ & $\mathbf{3 . 3 2 0 0 0 0}$ & $\mathbf{2 1 8 . 5 0 0 0}$ & $\mathbf{4 1 7 4 , 8 2 0}$ \\
\hline Std. Dev. & $\mathbf{0 . 1 8 7 8 5 1}$ & $\mathbf{3 5 6 . 6 0 8 5}$ & $\mathbf{3 5 0 1 . 4 6 7}$ & $\mathbf{6 5 2 8 5 . 6 8}$ \\
\hline Skewness & $\mathbf{0 . 8 8 2 0 9 1}$ & $\mathbf{3 . 1 1 8 5 9 2}$ & $\mathbf{1 . 3 1 9 4 8 9}$ & $\mathbf{7 . 1 4 2 1 5 9}$ \\
\hline Kurtosis & $\mathbf{2 1 . 2 6 2 8 6}$ & $\mathbf{1 5 . 5 6 0 0 9}$ & $\mathbf{3 . 6 8 6 7 5 2}$ & $\mathbf{5 2 . 0 1 3 3 6}$ \\
\hline Jarque-Bera & $\mathbf{1 5 1 4 , 8 9 9}$ & $\mathbf{8 8 4 . 9 6 2 6}$ & $\mathbf{3 3 . 4 6 1 2 5}$ & $\mathbf{1 1 7 2 8 . 5 8}$ \\
\hline Probability & $\mathbf{0 . 0 0 0 0 0 0}$ & $\mathbf{0 . 0 0 0 0 0 0}$ & $\mathbf{0 . 0 0 0 0 0 0}$ & $\mathbf{0 . 0 0 0 0 0 0}$ \\
\hline Sum & $\mathbf{8 . 6 3 2 3 4 2}$ & $\mathbf{2 5 9 9 1 . 1 3}$ & $\mathbf{2 9 9 6 8 8 . 5}$ & $\mathbf{1 4 8 9 9 8 6 .}$ \\
\hline Sum Sq. Dev. & $\mathbf{3 . 7 7 5 8 1 7}$ & $\mathbf{1 3 6 0 7 1 5 0}$ & $\mathbf{1 . 3 1 0 9}$ & $\mathbf{4 . 5 6 1 1}$ \\
\hline Observations & $\mathbf{1 0 8}$ & $\mathbf{1 0 8}$ & $\mathbf{1 0 8}$ & $\mathbf{1 0 8}$ \\
\hline
\end{tabular}

Source: Research Results, processed data (2021)

Based on Table 1 above, it can be seen that the number of observations made for income in this study were 108 observations. The lowest value of cryptocurrency return in this study is $-0.981481(-98.1 \%)$ and the highest value is $1.0000000(100 \% \%)$. The average value of income is 0.079929 with a standard deviation of $0.187851(18.785 \%)$. The standard deviation value is greater than the average value. It shows fluctuation return cryptocurrency high in the sample in this research.

Furthermore, the observations made for asset prices in this study were 108 observations. The lowest value of the cryptocurrency asset price in this study was 3.320000 USD and the highest value was 2359,300 USD. The average value of income is 240.6586 USD with a standard deviation of 356.6085. The standard deviation value is greater than the average value. This indicates a high fluctuation in asset prices in the sample in this study.

The observations made for the transaction volume in this study were 108 observations. The lowest number of transactions in this study is 218.5000 Unit Assets and the highest amount is 13850.40 Unit Assets. The average number of transactions in cryptocurrency assets is 2774,894 Asset Units with a standard deviation of 3501,467 . The standard deviation value is greater than the average value. This shows that the high fluctuation of transaction volume in the sample will affect this research.

The observations made for market capitalization in this study were 108 observations. The lowest value of the cryptocurrency asset market capitalization in this study is 4174,820 USD and the highest value is 486865.0 USD. The average market capitalization value of cryptocurrency assets is 13796.16 USD with a standard deviation of 65285.68. The standard deviation value is greater than the average value. This shows that the large market capitalization in the sample will affect this research.

\subsection{Classic Assumption Test Results}

\subsubsection{Normality Test}

Based on Figure 2 below, it can be seen that the probability value in the Jarque-Bera test is 0.000 where the value of is below the standard value of fault tolerance $(5 \%)$. Therefore, it can be concluded that in this study it is not normally distributed. 


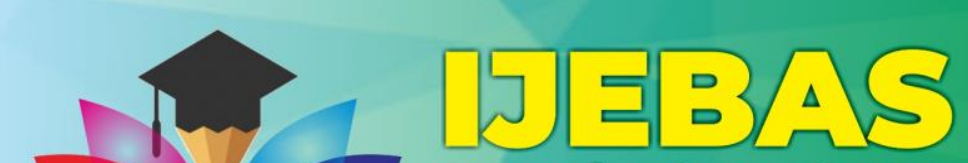

Table 2 Normality Test Path 1

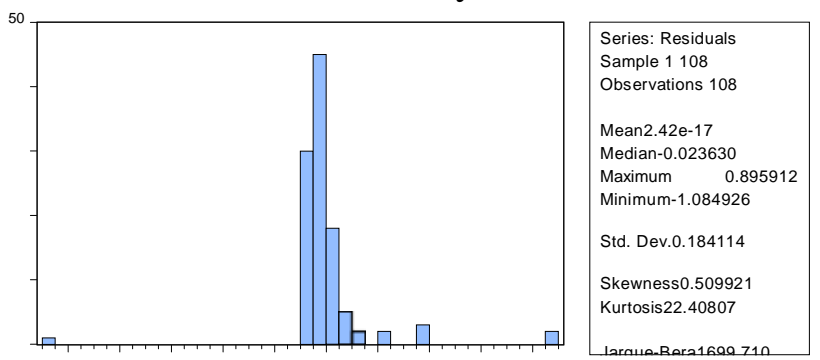

Source: Research Results, 2021

\subsubsection{Heteroscedasticity Test}

Table 3 Heteroscedasticity Test (Glajser)

\begin{tabular}{|c|r|r|r|c|}
\hline Variable & Coefficient & Std. Error & t-Statistics & Prob. \\
\hline C & 0.118983 & 0.020768 & 5.729164 & 0.0000 \\
\hline $\begin{array}{c}\text { Asset_Price } \\
\overline{\mathrm{X}}_{1}\end{array}$ & $-1.50 \mathrm{E}-06$ & $5.17 \mathrm{E}-05$ & -0.02903 & 0.9760 \\
\hline $\begin{array}{c}\text { Transaction } \\
\text { Volume } \mathrm{X}_{2}\end{array}$ & $-1.20 \mathrm{E}-05$ & $5.27 \mathrm{E}-00$ & -2.272115 & 0.2051 \\
\hline $\begin{array}{c}\text { Market } \\
\text { Capitalization } \mathrm{X}_{3}\end{array}$ & $-2.07 \mathrm{E}-07$ & $2.39 \mathrm{E}-07$ & -0.868201 & 0.3873 \\
\hline
\end{tabular}

Source: Research Results, 2021

Based on the table above, it can be seen that all independent variables in the Glajser test have probability values above 0.05 , therefore it can be concluded that there is no symptom of heteroscedasticity in this study.

\subsubsection{Multicollinearity Test}

Table 4 Multicollinearity Test

\begin{tabular}{|c|c|c|c|c|}
\hline & $\begin{array}{c}R C \\
\mathrm{Y}\end{array}$ & $\begin{array}{c}\text { Asset Price } \\
\mathrm{X} 1\end{array}$ & $\begin{array}{c}\text { Transaction } \\
\text { Volume X2 }\end{array}$ & $\begin{array}{c}\text { Market } \\
\text { Capitalization X3 }\end{array}$ \\
\hline $\begin{array}{c}\text { Return Cryptocurrency } \\
\mathrm{Y}\end{array}$ & 0.0349 & -3.9995 & -123.3479 & -254.6099 \\
\hline $\begin{array}{c}\text { Asset Price } \\
\text { X1 }\end{array}$ & -3.999 & 125992.1252 & 665456.0995 & -1494421.1349 \\
\hline $\begin{array}{c}\text { Transaction Volume } \\
\text { X2 }\end{array}$ & -123.3479 & 665456.0995 & 12146747.0420 & -16832448.8374 \\
\hline $\begin{array}{c}\text { Market Capitalization } \\
\text { X3 }\end{array}$ & -254.6099 & -1494421.1349 & -16832448.8374 & 4222754656.91802 \\
\hline
\end{tabular}

Source: Research Results, 2021

By table on shows that this model occurs multicollinearity by looking at the output between the independent variables in the regression where there is an output that exceeds 0.8 . 


\subsubsection{Autocorrelation Test}

Table 5 Autocorrelation Test

\begin{tabular}{|l|r|l|r|}
\hline R-squared & 0.96721 & Mean dependent var & -8.540663 \\
\hline Adjusted R-squared & 0.96456 & SD dependent var & 0.432772 \\
\hline SE of regression & 0.081471 & Akaike info criterion & -2.097481 \\
\hline Sum squared resid & 0.65711 & Schwarz criterion & -1.873970 \\
\hline Likelihood logs & 122.2640 & Hannan Quinn Criter. & -2.00685 \\
\hline F-statistics & 365.0269 & Durbin-Watson stat & 0.380779 \\
\hline Prob(F-statistic) & 0.000000 & & \\
\hline
\end{tabular}

Source: Research Results, 2021

Autocorrelation test from Table 4 above can be seen from the value of Durbin Watson in this study. The value of Durbin Watson in this study is 0.380779 . This value is between the tolerance values in the autocorrelation test, namely -2 and 2 . Therefore, it can be concluded that this study is free from autocorrelation symptoms, meaning that in this research model there is no interference with the correlation between the time periods used in each variable.

\subsection{Model Selection Technique}

The results of testing the three models in this study are as follows:

Table 6 Panel Data Model Regression Results

\begin{tabular}{|c|c|c|c|c|c|c|}
\hline \multirow[t]{2}{*}{ Variable } & \multicolumn{2}{|c|}{ CEM } & \multicolumn{2}{|l|}{ FEM } & \multicolumn{2}{|c|}{$\begin{array}{c}\text { BRA } \\
\text { KE }\end{array}$} \\
\hline & Coefficient & Prob. & Coefficient & Prob. & Coefficient & Prob. \\
\hline C & 0.107147 & 0.0000 & 0.107147 & 0.0000 & 1.899684 & 0.0001 \\
\hline $\begin{array}{l}\text { Asset Price } \\
\mathrm{X1}\end{array}$ & 3.020005 & 0.6165 & 3.020005 & 0.6165 & -0.769404 & 0.0000 \\
\hline $\begin{array}{l}\text { Transaction Volume } \\
\text { X2 }\end{array}$ & -1.190005 & 0.0538 & -1.190005 & 0.0538 & 1.295468 & 0.0000 \\
\hline $\begin{array}{l}\text { Market Capitalization } \\
\text { X3 }\end{array}$ & -9.720008 & 0.7267 & -9.720008 & 0.7267 & -0.644884 & 0.0000 \\
\hline
\end{tabular}

Source: Research Results, 2021

Based on the table above, it can be seen that all the coefficients and significance values for the panel data regression model based on the Common Effect Model (CEM), Fixed Effect Model (FEM) and Random Effect Model (REM) in this study.

\subsubsection{Chow Test (Chow Test)}

Table 7 Chow test

\begin{tabular}{|l|r|r|r|}
\hline \multicolumn{1}{|c|}{ Effects Test } & \multicolumn{1}{c|}{ Statistics } & \multicolumn{1}{c|}{ df } & \multicolumn{1}{c|}{ Prob. } \\
\hline Cross-section F & 0.32537 & $(1.103$ & 0.5696 \\
\hline Cross-section Chi-square & 0.340635 & & 0.5593 \\
\hline
\end{tabular}

Source: Research Results, 2021

Table 4.6 shows that the value of probability in the chow test of 0.5595 . This value is above the standard error tolerance value in this study, which is 0.05 . Therefore, based on the results of the Chow test, the best model in this study is the Common Effect Model (CEM), so it is not necessary to do a Hausman test to choose the best model between the Fixed effect model (FEM) and the random effect model (REM). 


\subsubsection{Panel Data Estimation}

Table 8 Panel Data Regression Estimation Results with Common Effect Model (CEM)

\begin{tabular}{|c|c|c|c|c|}
\hline Variable & Coefficient & Std. Error & t-Statistics & Prob. \\
\hline$\overline{\mathrm{C}}$ & 0.107147 & 0.024114 & 4.443379 & $\overline{0.0000}$ \\
\hline Asset_Price_X1 & 3.020005 & 6.0100005 & 0.502364 & 0.6165 \\
\hline Transaction_Volume_X2 & -1.190005 & 6.120006 & -1.950490 & 0.0538 \\
\hline Market_Capitalization_X3 & -9.720008 & 2.770007 & -0.350438 & 0.7267 \\
\hline R-squared & 0.039392 & & Mean dependent var & 0.07 \\
\hline Adjusted R-squared & 0.011682 & & SD dependent var & 0.18 \\
\hline SE of regression & 0.186751 & & Akaike info criterion & -0.481752 \\
\hline Sum squared resid & 3.627080 & & Schwarz criterion & -0.382414 \\
\hline Likelihood logs & 30.01462 & & $\begin{array}{l}\text { annan Quinn } \\
\text { riter. }\end{array}$ & -0.4414 \\
\hline F-statistics & 1.421587 & & Durbin-Watson stat & 1.3297 \\
\hline$\overline{\text { Prob(F-statistic) }}$ & 0.240704 & & & \\
\hline
\end{tabular}

Source: Research Results, 2021

Based on the table above, the regression equation model that can be arranged in this study is as follows:

$\mathrm{Y}=+\beta 1 \mathrm{X} 1+2 \mathrm{X} 2+3 \mathrm{X} 3+\mathrm{e} \mathrm{Y}=0.107147+3.020005 \mathrm{X} 1+(-1.190005 \mathrm{X} 2)+(-9.720008 \mathrm{X} 3)$ $+\mathrm{e}$

Based on the above equation, it can be seen that the constant value is 0.107147 . This shows that if the asset price, transaction volume and market capitalization have no value, then the cryptocurrency return will be constant at 0.107147 . Meanwhile, asset price has a positive (unidirectional) effect on cryptocurrency returns with a regression coefficient of 3.020005. This shows that if the asset price increases by $1 \%$, the cryptocurrency return will increase by $302,0005 \%$.

Furthermore, the transaction volume variable has a negative (not unidirectional) effect on cryptocurrency returns with a regression coefficient value of $(-1.190005)$. This shows that if the transaction volume experiences an increase of $1 \%$, the cryptocurrency return will decrease by $119,0005 \%$. While the market capitalization variable has a negative effect on cryptocurrency returns with a regression coefficient value of (- 9.720008), where if the market capitalization increases by $1 \%$ then the cryptocurrency returnwill experience a decline as big as $972,0008 \%$. The result of the coefficient of determination (Adjusted R Square) in this study is 0.011682 or $1.1682 \%$. These results show that asset price, transaction volume and market capitalization are able to explain the cryptocurrency return of $1.1682 \%$ while $98.8318 \%$ is explained by other variables not analyzed in this study.

Meanwhile, the significance value in the $\mathrm{F}$ test is 0.240704 , which is above the standard error tolerance value of 0.05 . Therefore, this shows that asset price, transaction volume and market capitalization simultaneously affect cryptocurrency returns.

\subsection{Hypothesis Testing Results and Discussion 4.4.1 Partial Test (t Test)}

a. Effect of Asset Price on Cryptocurrency Return (H1)

Based on the test results using the Eviews 10 application, it is known that the tcount value of the asset price is 0.502364 with a significant 0.6165 . The ttable value in this study calculated by $\mathrm{df}=\mathrm{nk}$ is 1.98282 with a significance of 0.05 . So it can be seen that asset price has a negative and insignificant effect on cryptocurrency returns. This is indicated by the results of the tcount (0.502364) ttable (1.98282) and the value significant 0.61650 .05 . So it 
can be concluded that the asset price variable has a negative and insignificant effect on return cryptocurrency.

\section{b. Effect of Transaction Volume Against Return Cryptocurrency (H2)}

Based on the test results using the Eviews 10 application, it is known that the tcount value of the transaction volume is -1.950490 with a significant 0.0538 . The value of ttable in this study is calculated by $\mathrm{df}=\mathrm{nk}$ is equal to 1.98282 with a significant 0.05 . Then it can be seen that the transaction volume has a negative and no effectsignificant to return cryptocurrency.

This is indicated by the results of the tcount $(-1.950490)<$ ttable $(1.98282)$ and the significant value is 0.05380 .05 . So it can be concluded that the transaction volume variable has a positive and insignificant effect on cryptocurrency returns.

\section{c. Effect of Market Capitalization against Return Cryptocurrency (H3)}

Based on the test results using the Eviews 10 application, it is known that the tcount value of market capitalization is -0.350438 with a significant 0.7267 . The value of table in this study calculated by $\mathrm{df}=\mathrm{nk}$ is 1.98282 with a significant 0.05 . So it can be seen that market capitalization has a negative and insignificant effect on cryptocurrency returns. This is indicated by the results of the tcount $(-0.350438)<$ ttable (1.98282) and the significant value is 0.72670 .05 . So it can be concluded that the market capitalization variable has a negative and insignificant effect on cryptocurrency returns.

\subsubsection{Simultaneous Test (F Test)}

Based on the test results using the Eviews 10 application, it was found that the results showed that variable asset price, transaction volume and market capitalization simultaneously on cryptocurrency returns. This is based on the results of Fcount of 1.421587 with a significant level of 0.240704 and the value of Ftable in this study calculated by df $=n k$ is 2.69 with a significance of 0.05 . Because the Fcount value is 1.421587 < Ftable value 2.69 and the significance probability value Fcount $0.240704>0.05$, it can be concluded that together the independent variables, namely asset price, transaction volume and market capitalization, have a negative and insignificant effect on the variable. dependent i.e. Return Cryptocurrency

\section{CONCLUSIONS AND SUGGESTIONS}

\subsection{Conclusion}

Based on the results of research and discussion, some conclusions can be drawn as follows.

1. The result of the coefficient of determination (Adjusted R Square) in this study is 0.011682 or $1.1682 \%$. This result shows asset price, transaction volume and market capitalizationable to explain return cryptocurrency of $1.1682 \%$ while $98.8318 \%$ is explained by other variables not analyzed in this study.

2. Asset price negative and insignificant effect on cryptocurrency returns. This is indicated by the results of the tcount $(0.502364)$ ttable $(1.98282)$ and the significant value is 0.61650 .05 .

3. Transaction volume negative and insignificant effect on cryptocurrency returns. This is indicated by the results of the tcount $(-1.950490)<$ ttable $(1.98282)$ and the significant value is 0.05380 .05 . 
4. Market capitalization negative and insignificant effect on cryptocurrency returns. That matter indicated by the results of the value of tcount $(-0.350438)<$ ttable $(1.98282)$ and the value of significant 0.72670 .05 .

5. Simultaneous test results show that the asset price, transaction volume and market capitalization variables on Cryptocurrency Returns have a negative and insignificant effect.

\subsection{Suggestion}

Based on the results of the research, discussion and conclusions obtained, the following suggestions can be given:

1. Suggestions for cryptocurrency exchange service providers, namely;

a. Preaching positive issues to be sentimental market Cryptocurrency getting better, improving Trading management and services to make consumers interested in buying Cryptocurrencies which in turn has implications for increasing cryptocurrency sales.

b. Pay attention to the pattern of asset price movements, transaction volumes and market capitalization because these aspects are very attractive to investors in conducting technical analysis and predicting the price movements of Crypto digital assets. It would be even more interesting if the service provider companyExchange Cryptocurrency providing services in the form of risk analysis and price predictions, of course, investors will be interested $\mathrm{i}$

\section{REFERENCES}

Andi, Prastowo. (2015). Creative Guide to Making Innovative Teaching Materials. Yogyakarta: Diva Press.

Ang, Robert. (2010). Indonesian Capital Market Smart Book 7th edition. Jakarta: Media Soft Indonesia.

(2012). Indonesian Capital Market Smart Book (The Intelligent Guide To Indonesian Capital Market). First Edition. Mediasoft Indonesia. Jakarta.

Arikunto, suharsimin. (2010). Research Management. PT. Reneka Cipta, Jakarta.

Arista and Astohar. 2012. "Analysis of Factors Affecting Stock Returns (Case of Manufacturing Companies that Go Public on the IDX for the period 2005-2009)". Journal of Applied Management and Accounting Sciences, Vol. 3, No. 1, May 2012.

Basthian Tantober et all (2019), Analysis of The Day Of The Week Effect on Virtual Currency Returns in the Cryptocurrency Market. Management Study Program, Faculty of Economics and Business, University of North Sumatra.

Bhiantara, IBP (2018). Cryptocurrency Blockchain Technology in the Digital Revolution Era. National Seminar on Informatics Engineering Education (SENAPATI), 9 (September),173-177.Retrieved from http://eproceeding.undiksha.ac.id/index.php/senapati/article/view/1204

Bhosale and Mavale. (2018). In vitro shoot multiplication in different species of banana. Asian J. Plant Sci. 1(3): 23 - 27. 
Bikbov, R., \& Chernov, M. (2010). No-Arbitrage Macroeconomic Determinants of The Yield Curve. Journal of Econometrics, 159(1), 166182.Https://Doi.Org/10.1016/J.Jeconom.2010.05.004.

Buchari Alma, (2011), Marketing Management and Service Marketing, Prints of Abandonment, Alfabeth, Bandung.

Dhika Khameswara, Tubagus and Wido Hidayatullah. (2014). Bitcoin Digital Money Future. Surya University.

Djati, SRR, \& Kamal, M. (2017). Theoretical Thinking Framework and Formulation of the Roa Hypothesis. Diponegoro Journal of Accounting, 6(3), 2337-3792. Retrieved From Https://Ejournal3.Undip.Ac.Id/Index.Php/Djom/Article/Viewfile/17462/16715.

Fakhruddin, Darmadji, Tjiptono and HM (2008). Capital Markets in Indonesia: A Question and Answer Approach. Edition 2. Jakarta: Salemba Empat Publishers.

Ghozali, Imam. (2011). Multivariate Analysis Application With IBM SPSS Program 19. Fifth edition. UNDIP research agency, Semarang.

Nurhisam, Luqman. (2017). Sharia Marketing Ethics, Vol. 4, No. 2. Inhttp://ejournal.stainpamekasan.ac.id/index.php/iqtishadia/article/view/1412,.

Olivia Angela. (2019). Factors Affecting Ethereum Price. Finance Program, Accounting Department, Faculty of Economics \& Communication Bina Nusantara University Jakarta, Indonesia 11480.

Parnia, S; Spearpoint, K, Fenwick, PB. (2017). Near death experiences, cognitive function and psychological outcomes of surviving cardiac arrest. resuscitation.

Pathirawasam, Chandrapala. (2009). The Relationship Between Trading Volume and Stock Returns. Tomas Bata University in Zlin, Journal. Faculty of Management and Economics

Petsching, Walter and Baumann, EH(2017). Critical Incident Reporting System (CIRS)

: a Fundamental Component of Risk Management in Health Care System to Enhause Patient Safety. Journal of Safety in Health Austria.

Raharjo, D., \& Muid, D. (2013). Analysis of the Effect of Fundamental Factors of Financial Ratios on Changes in Stock Prices. Accounting journal.

Kant, Ravi and Vishnoi, Himani;. 2011. "Green Tea (Camellia Sinensis) and Its Antioxidant Property: A Review”. IJPSR, Vol. 9. Num. 5. Pages: 1723-1736.

Sovbetov, Y., and Saka, H. (2018). Does it take two to tango: Interaction between Credit Default Swaps and National Stock Indices. Journal of Economics and Financial Analysis, 2(1), pp. 129-149. 


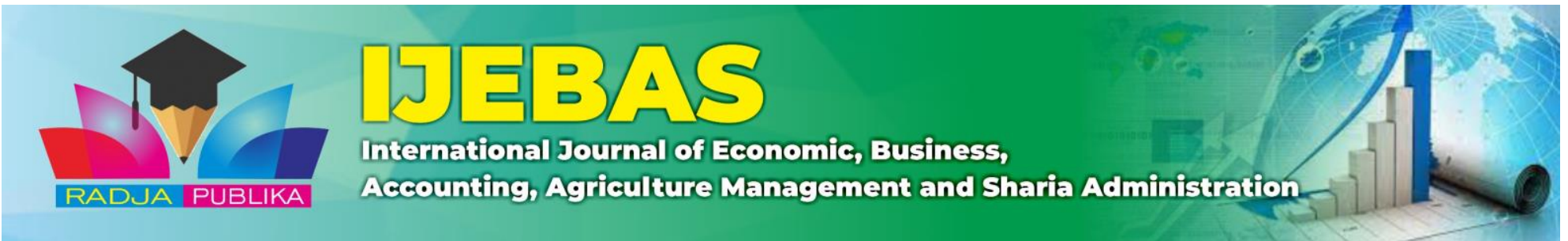

Sugiyono. (2016). Quantitative, Qualitative and R\&B Research Methods. Alphabeta, Bandung.

Tandelilin, E. (2010). Portfolio And Investment. Canisius.

Tikhomirov E. (1987). WHO Program for the Control of Hospital Infections.Chemiotherapia, 3:148-151.

Umam and Harry. (2017). Investment Management. Bandung. Loyal Library CV. Widyawati, R. (2015). Analysis of Factors Affecting Movement

Bitcoin Price Period August 17, 2010-December 31, 2014. Journal of Applied Microbiology.

Winarno, Budi. (2007). Public Policy: Theory and Process. Yogyakarta : Med Press ( Member of IKAPI ).

Yukun Liu Aleh Tsyvinski. (2018). Risks And Returns Of Cryptocurrencies. NBER Working Paper No. 24877 August 2018 JEL No. G12,G32.

https://fafaahmad.wordpress.com/2011/05/15/pp-no-71-tahun-2010-about standardaccounting-government/ 